\title{
SEISMIC PERFORMANCE EVALUATION OF RC BUILDING CONNECTED WITH AND WITHOUT X-BRACED FRICTION DAMPERS
}

\author{
H Eramma', Pulakeshi H L ${ }^{2}$ \\ ${ }^{1}$ Associate Professor, University BDT College of Engineering, Davangere 577004KARNATAKA INDIA \\ h.eramma@gmail.com \\ ${ }^{2} P G$ Student CADS, University BDT College of Engineering, Davangere 577004KARNATAKA INDIA \\ puli.civil@gmail.com.
}

\begin{abstract}
The dissertation work is concerned with the comparison of the seismic evaluation of RC buildings connected with and without friction dampers, the method carried out in terms of equivalent static, response spectrum and pushover analysis according to IS 1893:2002(part1) code. $G+5, G+10$ and $G+15$ storey buildings respectively are considered for the analysis. In this analysis for friction damper buildings, the dampers are connected at corners of all the buildings. The comparison of equivalent static method and response spectrum method by using finite element software package ETABS version 9.7.4 is used to perform the modeling and analysis of G+5, $G+10$ and $G+15$ storey buildings by considering the seismic zone IV as per IS 1893:2002(part 1) code. For analysis various IS codes have been referred. For Gravity load combination IS 456:2000 and for 0.9, 1.2 and 1.5 seismic load combinations as per IS 1893:2002 (part 1) code is referred. In this study building model analysis carried out namely gravity, equivalent static and response spectrum in longitudinal direction \& transverse direction discussed and comparisons of codal values of the software analysis values. Results of these analyses are discussed in terms of the time period, storey displacement, storey drift and base shear. From these results it is concluded that time period, storey displacement and storey drift will be more in regular buildings compare with the friction damper buildings, whereas the base shear will be less in regular buildings compare with the friction damper buildings.
\end{abstract}

Keywords - Friction dampers; Fundamental natural time period, Base shear, Lateral displacement and Storey drift. ****.

\section{INTRODUCTION}

In recent years, an effort is being made to develop and improve the structural control devices to reduce seismic impact in buildings and bridges. Full scale implement of active control systems is difficult as it is expensive and less reliable. Passive supplemental damping systems such as base isolation viscoelastic dampers and tuned mass dampers are widely used in structures to reduce the dynamic response. Semi-active damping systems i.e. variable-orifice fluid dampers, controllable friction devices, variablestiffness devices, smart tuned mass dampers and tuned liquid dampers, are more effective in mitigating dynamic response than active and passive damping system. During an earthquake, seismic energy is input into the structure which results in increased vibrational response. Mechanical devices e.g. dampers are provided throughout the height of structure to increase the damping hence reduce the response either by absorbing or dissipating energy. Friction dampers dissipate specifically kinetic energy through sliding of plate /surfaces. It can be equivalent to $30 \%$ critical damping ratio. Structural damage is categorized as local and global. Global damage detection techniques are based on variation in dynamics of structures such as stiffness, mass, damping and vibration modes. Structural damage results in a reduction in structure stiffness and in the modal parameters of building structures. Approximately 5\% change in natural frequency is considered essential for damage detection. To improve seismic response friction dampers is provided as X-brace. Energy dissipation capacity depends upon its damping coefficient \& non-linearity is defined by the damping exponent. Results show that using friction dampers to building can effectively reduce the building responses by selecting optimum damping coefficient i.e. when the building is connected to the friction dampers, can control both displacements and accelerations of the building. Further damper at appropriate locations can significantly reduce the earthquake response. The reduction in responses when MDOF building connected with 50\%, 40\%, 30\% of the dampers at appropriate locations is almost as much as when they are connected at all floors.

\section{METHODOLOGIES FOR SEISMIC}

\section{EVALUATION}

This research involves the various analysis techniques to determine the lateral forces ranging from purely linear to non-linear inelastic analysis. In India the Standardized method of analysis is followed by using a code - IS1893 (Part 1):2002 - "Criteria for Earthquake resistant design of structures". The seismic performance of building connected with and without friction dampers is carried out by Gravity analysis, Equivalent static analysis, Response spectrum analysis and Push-over analysis respectively. 
Table: 1 Load combinations as per IS: 1893-2002 and IS: 875(Part3)-1987

\begin{tabular}{|c|c|}
\hline Load Combination & Load Factors \\
\hline Gravity analysis & $1.5(\mathrm{DL}+\mathrm{LL})$ \\
\hline \multirow{4}{*}{ Equivalent static analysis } & $1.2(\mathrm{DL}+\mathrm{LL} \pm \mathrm{EQX})$ \\
\cline { 2 - 2 } & $1.2(\mathrm{DL}+\mathrm{LL} \pm \mathrm{EQY})$ \\
\cline { 2 - 2 } & $1.5(\mathrm{DL} \pm \mathrm{EQX})$ \\
\cline { 2 - 2 } & $1.5(\mathrm{DL} \pm \mathrm{EQY})$ \\
\cline { 2 - 2 } & $0.9(\mathrm{DL} \pm \mathrm{EQX})$ \\
\hline \multirow{4}{*}{ Response spectrum analysis } & $0.9(\mathrm{DL} \pm \mathrm{EQY})$ \\
\cline { 2 - 2 } & $1.2(\mathrm{DL}+\mathrm{LL} \pm \mathrm{RSX})$ \\
\cline { 2 - 2 } & $1.2(\mathrm{DL}+\mathrm{LL} \pm \mathrm{RSY})$ \\
\cline { 2 - 2 } & $1.5(\mathrm{DL} \pm \mathrm{RSX})$ \\
\cline { 2 - 2 } & $1.5(\mathrm{DL} \pm \mathrm{RSY})$ \\
\cline { 2 - 2 } & $0.9(\mathrm{DL} \pm \mathrm{RSX})$ \\
\cline { 2 - 2 } & $0.9(\mathrm{DL} \pm \mathrm{RSY})$ \\
\hline
\end{tabular}

\section{ILLUSTRATIVE MODAL FRAME}

The below table 1 shows the details of building considered for this dissertation work. Link properties of friction dampers are self-mass $\left(0.225 \mathrm{KN} \mathrm{sec} / \mathrm{m}^{2}\right)$, effective stiffness (0.2 to 1.2 times the initial stiffness of frame structures) and damping co-efficient. Initial stiffness of modeled frame structures is determined from non-linear static analysis (Pushover Curve) and damping co-efficient is determined from Eq.(i). Damping co-efficient is a function of structure mass, stiffness and damping ratio. In this dissertation work the damping ratio is taken as $5 \%$ of critical value and mass of frame structure is computed by using total gravity dead loads.

Damp coeff. $=\xi \times 2 \sqrt{\text { Stiffness } K i * M a s s}$

Table 2: Detail data of building studied

\begin{tabular}{|c|c|c|c|}
\hline Sl. No. & \multicolumn{3}{|c|}{ DESIGN DATA FOR ALL THE BUILDINGS } \\
\hline 1 & \multicolumn{3}{|c|}{ Details of building } \\
\hline i) & \multicolumn{2}{|l|}{ Structure } & OMRF \\
\hline ii) & \multicolumn{2}{|c|}{ Number of storey } & $\mathrm{G}+5, \mathrm{G}+10 \& \mathrm{G}+15$ \\
\hline iii) & \multicolumn{2}{|c|}{ Type of building } & Irregular and Unsymmetrical in plan \\
\hline iv) & \multirow{2}{*}{ Storey height } & Ground storey & $4.00 \mathrm{~m}$ \\
\hline v) & & Upper storey & $3.50 \mathrm{~m}$ \\
\hline vi) & \multicolumn{2}{|c|}{ Type of building use } & Commercial \\
\hline vii) & \multicolumn{2}{|l|}{ Seismic zone } & IV \\
\hline 2 & \multicolumn{3}{|c|}{ Material Properties } \\
\hline i) & \multicolumn{2}{|c|}{ Grade of concrete } & $\mathrm{M}_{25} \& \mathrm{M}_{30}$ \\
\hline ii) & \multicolumn{2}{|c|}{ Grade of Steel } & $\mathrm{Fe} 415$ \\
\hline iii) & \multicolumn{2}{|c|}{ Density of reinforced concrete } & $25 \mathrm{kN} / \mathrm{m}^{3}$ \\
\hline iv) & \multicolumn{2}{|c|}{ Density of Steel } & $78.50 \mathrm{kN} / \mathrm{m} 3$ \\
\hline v) & \multicolumn{2}{|c|}{ Young's modulus of $\mathrm{M}_{25}$ concrete, $\mathrm{E}_{\mathrm{c}}$} & $25000000.00 \mathrm{kN} / \mathrm{m}^{2}$ \\
\hline vi) & \multicolumn{2}{|c|}{ Young's modulus of $\mathrm{M}_{30}$ concrete, $\mathrm{E}_{\mathrm{c}}$} & $27386127.87 \mathrm{kN} / \mathrm{m}^{2}$ \\
\hline vii) & \multicolumn{2}{|c|}{ Young's modulus steel, $\mathrm{E}_{\mathrm{s}}$} & $200000000 \mathrm{kN} / \mathrm{m}^{2}$ \\
\hline viii) & \multicolumn{2}{|c|}{ Poisson's ratio for Concrete } & 0.175 \\
\hline ix) & \multicolumn{2}{|c|}{ Poisson's ratio for Steel } & 0.300 \\
\hline 3 & \multicolumn{3}{|c|}{ Member properties } \\
\hline $\mathbf{a}$ & \multicolumn{2}{|l|}{ Slab } & \\
\hline i) & \multicolumn{2}{|l|}{ Grade } & $\mathrm{M}_{25}$ \\
\hline ii) & \multicolumn{2}{|l|}{ Thickness } & $0.150 \mathrm{~m}$ \\
\hline b & \multicolumn{2}{|l|}{ Beam } & \\
\hline i) & \multicolumn{2}{|l|}{ Grade } & $\mathrm{M}_{25}$ \\
\hline ii) & \multicolumn{2}{|c|}{ Size ( for all storey ) } & $0.23 \times 0.45 \mathrm{~m}$ \\
\hline c & \multirow{2}{*}{\multicolumn{2}{|c|}{$\begin{array}{l}\text { Column } \\
\text { Grade }\end{array}$}} & \\
\hline i) & & & $\mathrm{M}_{30}$ \\
\hline ii) & \multicolumn{2}{|c|}{ Size ( for G+05 storey ) } & $0.30 \times 0.30 \mathrm{~m}$ \\
\hline iii) & \multicolumn{2}{|c|}{ Size ( for G+10 storey ) } & $0.45 \times 0.45 \mathrm{~m}$ \\
\hline
\end{tabular}




\begin{tabular}{|c|c|c|c|}
\hline iv) & \begin{tabular}{|l} 
Size ( for G+15 storey ) \\
\end{tabular} & & $0.60 \times 0.60 \mathrm{~m}$ \\
\hline 4 & \multicolumn{3}{|c|}{ Type of Loads \& their intensities } \\
\hline i) & \multicolumn{2}{|l|}{ Floor finish } & $1.75 \mathrm{kN} / \mathrm{m}^{2}$ \\
\hline ii) & \multicolumn{2}{|l|}{ Roof finish (DPC) } & $2 \mathrm{kN} / \mathrm{m}^{2}$ \\
\hline iii) & \multicolumn{2}{|l|}{ Live load on floors } & $3.5 \mathrm{kN} / \mathrm{m}^{2}$ \\
\hline iv) & \multicolumn{2}{|l|}{ Live load on roof } & $1.75 \mathrm{kN} / \mathrm{m}^{2}$ \\
\hline 5 & \multicolumn{3}{|l|}{ Seismic properties } \\
\hline i) & \multicolumn{2}{|l|}{ Zone factor $(\mathrm{Z})$} & 0.24 \\
\hline ii) & \multicolumn{2}{|l|}{ Importance factor ( I ) } & 1 \\
\hline iii) & \multicolumn{2}{|c|}{ Response reduction factor $(\mathrm{R})$} & 5 \\
\hline iv) & \multicolumn{2}{|l|}{ Soil type } & II \\
\hline v) & \multicolumn{2}{|l|}{ Damping ratio } & 0.005 \\
\hline 6 & \multicolumn{3}{|c|}{ Link ( Friction damper ) properties } \\
\hline i) & \multicolumn{2}{|l|}{ Mass ( for all storey ) } & $0.225 \mathrm{kN}$ \\
\hline ii) & \multicolumn{2}{|l|}{ Weight ( for all storey ) } & $2.25 \mathrm{kN}$ \\
\hline iii) & \multicolumn{2}{|c|}{ Rotational Ineria (for $1,2 \& 3$ ) } & 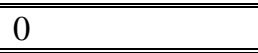 \\
\hline iv) & \multicolumn{2}{|l|}{ Effective stiffness, $\mathrm{K}_{\mathrm{e}}$} & \\
\hline \multirow[b]{2}{*}{$\mathrm{a}$} & \multirow{2}{*}{$\begin{array}{l}\text { For } \\
\text { storey }\end{array}$} & along $\mathrm{X}$ direction & $109198.28 \mathrm{kN} / \mathrm{m}$ \\
\hline & & along Y direction & $102476.73 \mathrm{kN} / \mathrm{m}$ \\
\hline \multirow{2}{*}{$\mathrm{b}$} & \multirow{2}{*}{$\begin{array}{ll}\begin{array}{l}\text { For } \\
\text { storey }\end{array} & \mathrm{G}+10 \\
\end{array}$} & along $\mathrm{X}$ direction & $70464.38 \mathrm{kN} / \mathrm{m}$ \\
\hline & & along Y direction & $66642.07 \mathrm{kN} / \mathrm{m}$ \\
\hline \multirow[b]{2}{*}{ c } & \multirow{2}{*}{$\begin{array}{l}\text { For } \\
\text { storey }\end{array}$} & along $\mathrm{X}$ direction & $56462.03 \mathrm{kN} / \mathrm{m}$ \\
\hline & & along Y direction & $56462.03 \mathrm{kN} / \mathrm{m}$ \\
\hline v) & \multicolumn{2}{|l|}{ Effective damping, $\mathrm{K}_{\mathrm{e}}$} & \\
\hline \multirow{2}{*}{$\mathrm{a}$} & \multirow{2}{*}{$\begin{array}{l}\text { For } \\
\text { storey }\end{array}$} & along $\mathrm{X}$ direction & $3570.50 \mathrm{kN}-\mathrm{s} / \mathrm{m}$ \\
\hline & & along Y direction & $3458.87 \mathrm{kN}-\mathrm{s} / \mathrm{m}$ \\
\hline \multirow{2}{*}{$\mathrm{b}$} & \multirow{2}{*}{\begin{tabular}{|l} 
For \\
storey
\end{tabular}} & along $\mathrm{X}$ direction & $3954.00 \mathrm{kN}-\mathrm{s} / \mathrm{m}$ \\
\hline & & along Y direction & $3845.26 \mathrm{kN}-\mathrm{s} / \mathrm{m}$ \\
\hline \multirow{2}{*}{$\mathrm{c}$} & \multirow{2}{*}{$\begin{array}{ll}\text { For } & \text { G+15 } \\
\text { storey } & \end{array}$} & along $\mathrm{X}$ direction & $4339.23 \mathrm{kN}-\mathrm{s} / \mathrm{m}$ \\
\hline & & along Y direction & $4339.23 \mathrm{kN}-\mathrm{s} / \mathrm{m}$ \\
\hline
\end{tabular}

\section{RESULTS AND DISCUSSIONS}

The results obtained in terms of natural time period, base shear, lateral displacement and storey drift for different building models considered for different types of analysis carried out namely gravity load analysis, equivalent static analysis, and response spectrum analysis are presented. An effort has made to study the behavior of irregular RC bare frame buildings in comparison with $\mathrm{RC}$ buildings having friction dampers.

\section{A. Natural Time Period}

The fundamental natural periods obtained for the seismic designed building models is plotted in fig. 1. From the plot it is very clear that, stiffness of the building is directly proportional to its natural frequency and hence inversely proportional to the natural period. That is, if the stiffness of building is increased the natural period goes on decreasing. And as the natural frequency of the taller buildings is low due to the less stiffness, the natural period goes on increasing for sixteen storeyed buildings.

The comparison of natural period presented in the table or plot shows that, the code IS 1893 (part-I) 2002 uses empirical formula to calculate natural period which is directly depends on the height of the building. Whereas the analytical procedure calculates the natural period on the basis of mass and stiffness of the building (Eigen value and

Eigen vectors).With this code doesn't consider the irregular effects on the natural period of vibration of the building.

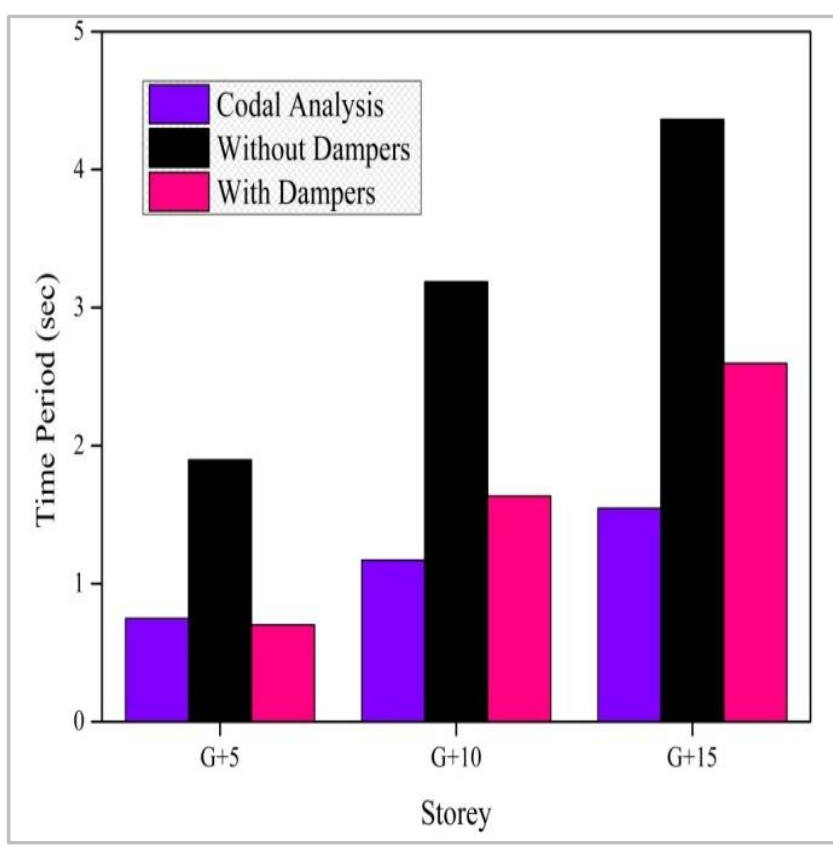

Fig. 1: Natural time period (seconds) profile for all Storey buildings for codal and analytical load combination as per IS 1893 (Part 1) -2000. 


\section{B. Base Shear}

Table 2: Base shear and scaling factors for all models for 1.2(DL+LL+EQL) combination

Model-I: Without Friction Dampers Building and

Model-II: With Friction Dampers Building

The base shear is a function of mass, stiffness, height, and the natural period of the building structure. But the Equivalent static method considers only the mass and natural period of the building. Moreover the basic assumption in the equivalent static method is that only first mode of vibration of building governs the dynamics.In dynamic response spectrum, all the modes of the building are considered, and first mode governs in the shorter buildings and as the storey increases for tall buildings, the flexibility increases and higher modes come into picture.

Hence base shears obtained from the equivalent static method are larger than the dynamic response spectrum method. From above tables 2 shows the results for gravity and seismic analysis of 1.2(DL+LL+EQL) combination for $\mathrm{G}+5, \mathrm{G}+10$ and $\mathrm{G}+15$ storey for model I and II for static base shear is more for same models response base shear is less compared to static base shear.

\section{Lateral displacement}

Table 3: Lateral displacements $(\mathrm{mm})$ of $\mathrm{G}+5$ storey building in longitudinal direction for seismic combination $1.2(\mathrm{DL}+\mathrm{LL}+\mathrm{EQX})$ and 1.2(DL+LL+RSX).

\begin{tabular}{|c|c|c|c|c|c|c|}
\hline \multirow{3}{*}{ Storey } & \multirow{2}{*}{\multicolumn{2}{|c|}{$\begin{array}{l}\text { Equivalent static method } \\
\text { Displacement (mm) }\end{array}$}} & \multirow{3}{*}{$\begin{array}{l}\text { Reduction of } \\
\text { displacement } \\
\text { in \% }\end{array}$} & \multirow{2}{*}{\multicolumn{2}{|c|}{$\begin{array}{l}\text { Response spectrum method } \\
\text { Displacement }(\mathrm{mm})\end{array}$}} & \multirow{3}{*}{$\begin{array}{l}\text { Reduction of } \\
\text { displacement } \\
\text { in \% }\end{array}$} \\
\hline & & & & & & \\
\hline & Model I & Model II & & Model I & Model II & \\
\hline 6 & 86.70 & 13.10 & 84.89 & 82.40 & 10.00 & 87.86 \\
\hline 5 & 80.40 & 10.40 & 87.06 & 77.50 & 8.00 & 89.68 \\
\hline 4 & 68.80 & 7.70 & 88.81 & 68.30 & 5.90 & 91.36 \\
\hline 3 & 53.30 & 5.10 & 90.43 & 55.00 & 3.80 & 93.09 \\
\hline 2 & 35.40 & 2.70 & 92.37 & 38.30 & 2.00 & 94.78 \\
\hline 1 & 16.70 & 1.00 & 94.01 & 18.80 & 0.70 & 96.28 \\
\hline 0 & 0.00 & 0.00 & 0.00 & 0.00 & 0.00 & 0.00 \\
\hline
\end{tabular}

$\mathrm{G}+5$ Longitudinal Direction for Seismic 1.2 Combination

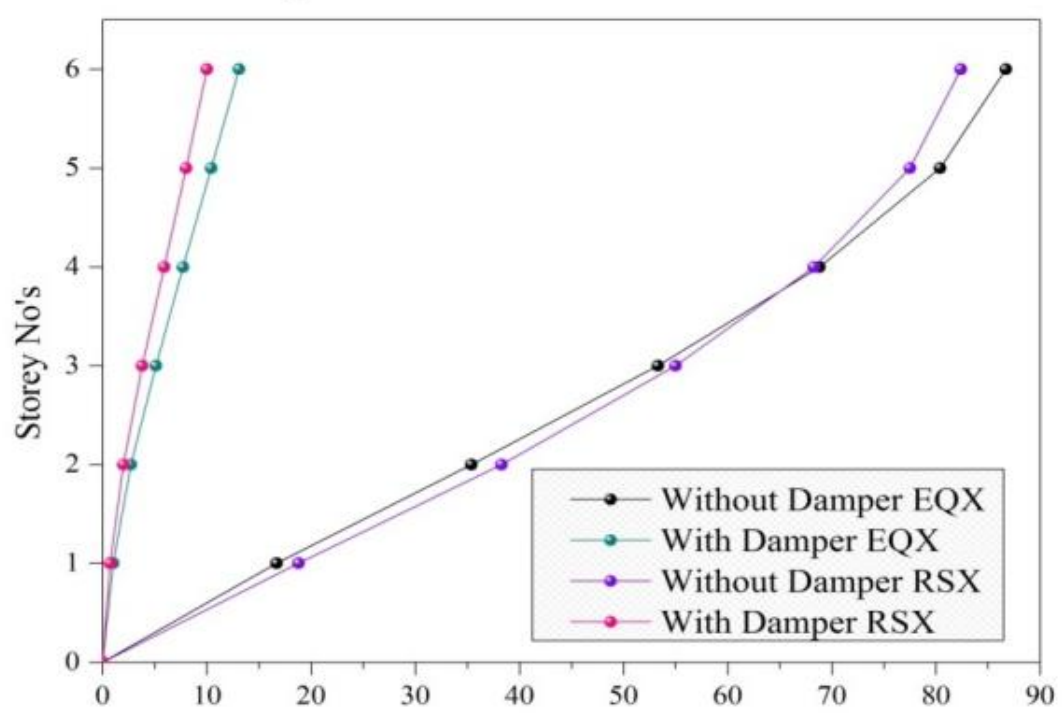

Lateral Displacement (mm)

Fig. 2: Lateral displacements $(\mathrm{mm})$ profile for $\mathrm{G}+5$ storey in longitudinal direction by seismic 1.2 EQX and RSX. 


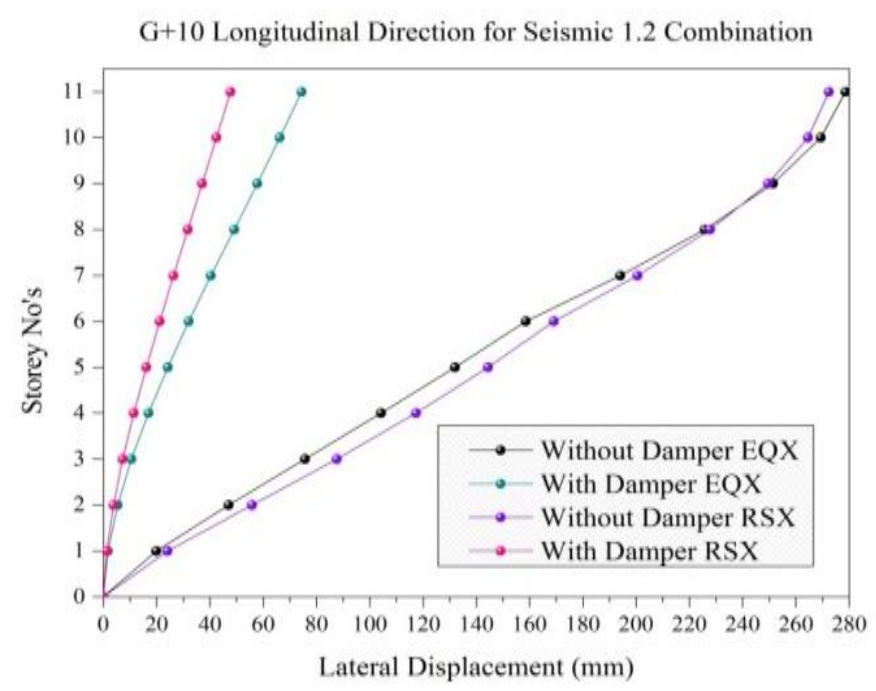

Fig. 3: Lateral displacements (mm) profile for G+10 storey in longitudinal direction by seismic 1.2 EQX and RSX.

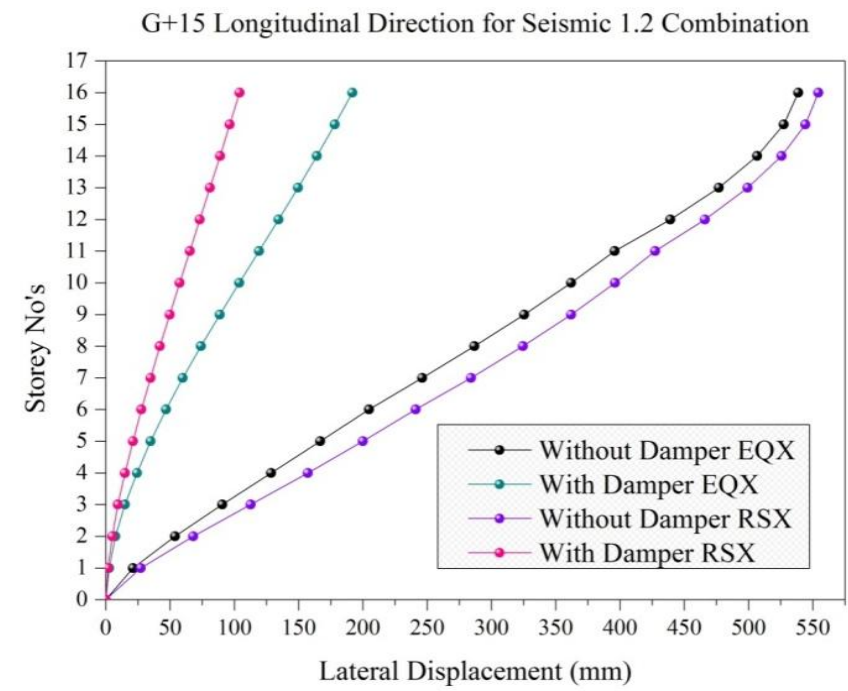

Fig. 4: Lateral displacements (mm) profile for G+15 storey in longitudinal direction by seismic 1.2 EQX and RSX.

From the tables and figs. it is observed that lateral displacement for model I and II when compared model I has displaced more than model II and they vary have a roof displacement for equivalent static and response spectrum method in longitudinal direction for 1.2 combination i.e. model II got $87.86 \%$ reduction in G+5 model, $82.49 \%$ reduction in $\mathrm{G}+10$ model and $81.26 \%$ in $\mathrm{G}+10$ model as compare to model I.

\section{Storey Drift}

According to IS 1893(Part 1):2002 clause 7.11.1 Storey drifts limitations are explained that the Storey drifts in any storey due to the minimum specified design lateral force, with partial load factor of 1.0 shall not exceed 0.004 times the storey height. For $4.00 \mathrm{~m}$ storey height the storey drift has got $16.00 \mathrm{~mm}$ and for $3.5 \mathrm{~m}$ storey height has got 14.00 $\mathrm{mm}$.

Table 4: Storey drifts $(\mathrm{mm})$ of G+5 storey building in longitudinal direction for seismic combination 1.2(DL+LL+EQX) and

\begin{tabular}{|c|c|c|c|c|c|c|}
\hline \multirow[t]{2}{*}{ Storey } & \multicolumn{2}{|c|}{$\begin{array}{l}\text { Equivalent static method } \\
\text { Storey drift }(\mathrm{mm})\end{array}$} & \multirow{2}{*}{$\begin{array}{l}\text { Reduction of } \\
\text { Storey drift } \\
\text { in \% }\end{array}$} & \multicolumn{2}{|c|}{$\begin{array}{l}\text { Response spectrum method } \\
\text { Storey drift }(\mathrm{mm})\end{array}$} & \multirow{2}{*}{$\begin{array}{l}\text { Reduction of } \\
\text { Storey drift } \\
\text { in } \%\end{array}$} \\
\hline & Model I & Model II & & \begin{tabular}{|l|} 
Model I \\
\end{tabular} & Model II & \\
\hline 6 & 1.81 & 1.01 & 44.20 & 1.80 & 0.98 & 45.56 \\
\hline 5 & 3.30 & 1.03 & 68.79 & 3.18 & 1.01 & 68.24 \\
\hline 4 & 4.44 & 0.99 & 77.70 & 4.22 & 0.98 & 76.78 \\
\hline 3 & 5.11 & 0.87 & 82.97 & 4.98 & 0.87 & 82.53 \\
\hline 2 & 5.34 & 0.65 & 87.83 & 5.60 & 0.65 & 88.39 \\
\hline 1 & 4.17 & 0.29 & 93.05 & 4.71 & 0.28 & 94.06 \\
\hline 0 & 0.00 & 0.00 & 0.00 & 0.00 & 0.00 & 0.00 \\
\hline
\end{tabular}


G+5 Longitudinal Direction for Seismic 1.2 Combination

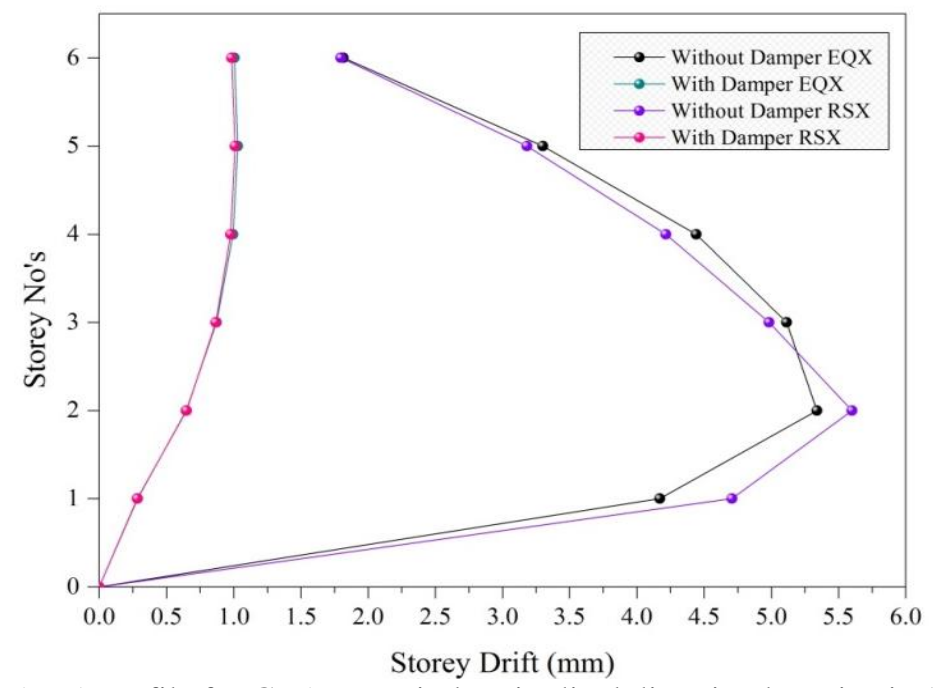

Fig.5: Storey drifts (mm) profile for G+5 storey in longitudinal direction by seismic 1.2 EQX and RSX.

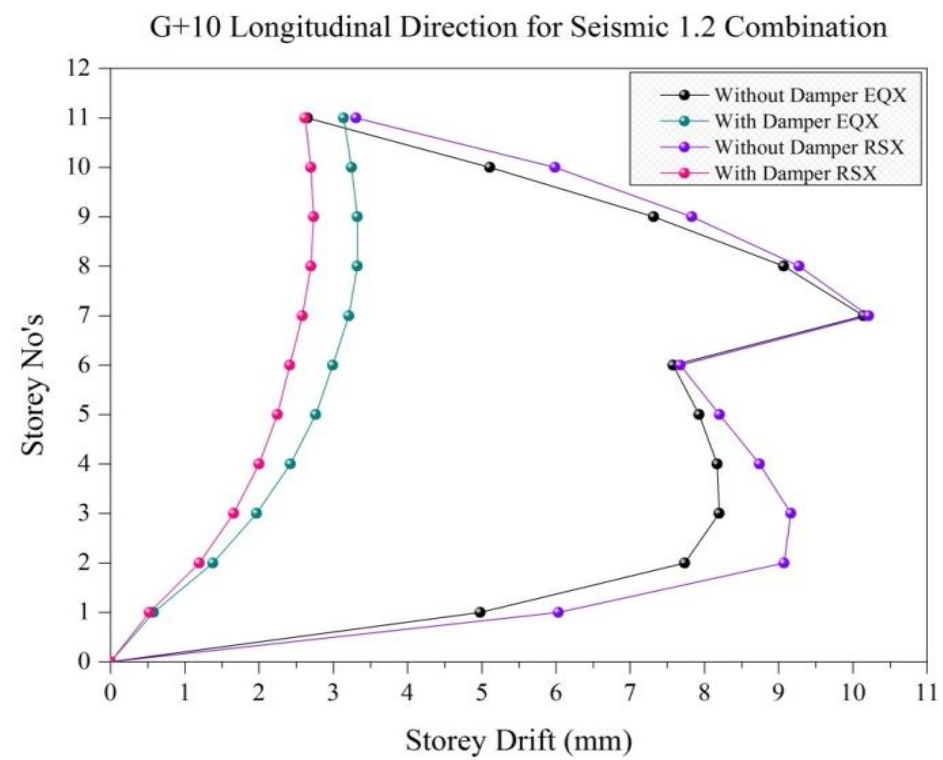

Fig.6:Storey drifts $(\mathrm{mm})$ profile for $\mathrm{G}+10$ storey in longitudinal direction by seismic 1.2 EQX and RSX.

G+5 Longitudinal Direction for Seismic 1.2 Combination

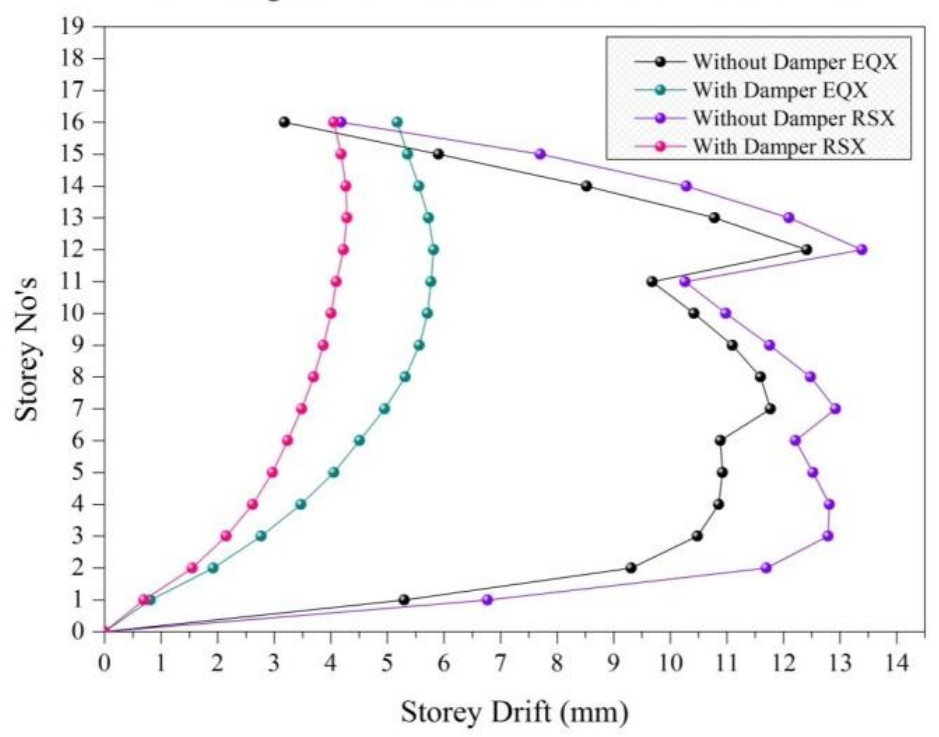

Fig. 7: Storey drifts (mm) profile for $\mathrm{G}+15$ storey in longitudinal direction by seismic 1.2 EQX and RSX. 
From the table and fig. it is observed that storey drift for model I and II when compared model I has drift more than model II and they vary have a roof displacement for equivalent static and response spectrum method in longitudinal direction for 1.2 combination i.e. model II got maximum drift $94.02 \%$ reduction in $\mathrm{G}+5$ model, $91.38 \%$ reduction in $\mathrm{G}+10$ model and $89.69 \%$ in $\mathrm{G}+10$ model as compare to model I.

\section{CONCLUSION}

In the present study $\mathrm{G}+5, \mathrm{G}+10$ and $\mathrm{G}+15$ Storey frames are studied with X-braced friction dampers. Based on this study following conclusions can be drawn.

- Considering all type of combinations the best combination for which performance point has to be taken for the analysis so, 1.2 combination is the best combination.

- The analytical natural periods do not agree with the natural periods obtained from the empirical expressions of the code for irregular buildings, therefore to design such buildings dynamic analysis should be carried out.

- The fundamental natural period of the structure (Model II) decrease due to the presence of friction damper in the buildings.

- Base shear increases with the increase of mass and stiffness of friction dampers in buildings and it decreases for the buildings without friction dampers.

- Compared to the building connected with friction dampers the storey displacement is increases with increase in stiffness of the buildings.

- The top storey lateral displacement of Model II get reduced about $88 \%$ for $\mathrm{G}+5$ model, $82 \%$ for $\mathrm{G}+10$ Model and $81 \%$ for $\mathrm{G}+15$ Model respectively when compare to Model I.

- The storey drift will decrease as the flexibility decreases in building, due to dampers connected to the buildings.

- The storey drift of Model II get reduced about $94 \%$ for G+5 model, 91\% for G+10 Model and $89 \%$ for $\mathrm{G}+15$ Model respectively when compare to Model I.

- The friction devices limit the amount of energy that is input into the structure.

- The amplitude of displacements, natural time periods, storey drifts and accelerations is considerably reduced.

- The result shows that, the buildings with friction dampers are more vulnerable compared to

- buildings without friction dampers.

- The building can be tuned for optimum response without resorting to expensive devices.

\section{REFERENCES}

[1]. Bhaskararao, A. V. and Jangid, R.S.(2007). "Optimum friction damper for connecting adjacent SDOF structures for harmonic and stationary whitenoise random excitations", Earthquake Engineering and Structural dynamics, vol 36, Pp 563-571.

[2]. Bhaskararao, A.V. and Jangid, R.S.(2004). "Seismic Response of Adjacent Buildings Connected With Dampers", 13th World Conference on Earthquake Engineering, Pp 3143.
[3]. Dong-Dong, GE, Hong-Ping ZHU. And Dan-Sheng, WANG (2010). "Seismic Response Analysis of Damper-Connected Adjacent Structures With Stochastic Parameters", Journal of Zhejiang University, Volume 11, No 6, Pp 402-414.

[4]. "Earthquake Resistant Design of Structures" Textbook by Pankaj Agarwal and Manish Shrikande, Volume No. ii.

[5]. Huangsheng, S. and Linuo, C (2011). "Connecting Parameter Study on Adjacent Structures Linked by Dampers," Advanced Materials Research, Pp 243-249 and 3832-3838.

[6]. IS 875 Part 1 and 2, Code of Practice for Design Loads (Other than Earthquake) for Buildings and Structures.

[7]. IS 1893:2002, Criteria for Earthquake resistant design of structures Part 1 General Provisions and Buildings (Fifth Revision).

[8]. L. Landi, P.P. Diotallevi \& G. Castellari (2012). "A Procedure for the Design of Viscous Dampers to Be Inserted in Existing Plan-Asymmetric Buildings", 15 WCE LISBOA.

[9]. Pak. J. Engg. \& Appl. "Improved Seismic Response RC Frame Structures by Using Fluid Viscous Dampers". Vol. 13, July, 2013 (Pp. 8-18).

[10]. Patel C.C. and Jangid, R.S (2010). "Seismic Response of Dynamically Similar Adjacent Structures Connected With friction Dampers", The IES Journal of Civil \& Structural Engineering, Vol 3, Pp 1-13, Febraury.

[11]. Xu, Y.L, He, Q and Ko, J.M (1999). “ Dynamically response of damper-connected adjacent buildings under earthquake excitation," Engineering Structures, Vol 21, Pp 135-148.

[12]. Yang, Xu, W.L and Lu, X.L(2003). "Experimental Seismic Study of Adjacent Buildings with Fluid Viscous Dampers", Journals of Structural Engineering, Pp 197-205.

[13]. Zhang, W.S. and Xu, Y.L (1999), "Dyanamic Characteristics and Seismic Response of Adjacent Buildings Linked By Discrete Dampers", Earthquake Engineering And Structural Dynamics, Vol 28, Pp 1163-1185. 